\title{
HARDNESS STUDY OF LOCALLY PRODUCED ALUMINIUM ALLOY MOTORCYCLE CLUTCH HANDLE PRODUCED BY SAND, DIE AND IMPORTED CASTING
}

Ukachi P. A., Igbasanmi O. E. \& Afuye,E.K.

Department of Mechanical Engineering, Federal Polytechnic,Ado- Ekiti, Nigeria.

E-mail:- patrickukachi@gmail.com

\begin{abstract}
Foundry is a production process in which pattern is used to prepare mould by ramming suitable prepared sand to it. The pattern when withdrawn leaves a cavity in which molten metal is melted and poured into it. When it solidifies, it is extracted and fettled to suit the purpose it is made to serve. This research X-ray into the foundry production process of motorcycle clutch handle produced by sand and die casting process and testing of the hardness of each as to compare the hardness with imported castings. A hardness property value is the result of a defined measurement procedure. The hardness test of sand cast aluminum alloy motorcycle clutch handle, die cast aluminum alloy motorcycle clutch handle and imported aluminum alloy motorcycle clutch handle were carried out with Vickers micro hardness tester and the results obtained revealed that in the average of the specimens, sand casting has the hardness of $127.65 \mathrm{HV}$, die casting has the hardness of $124.25 \mathrm{HV}$ while imported casting has the hardness of $89.05 \mathrm{HV}$.
\end{abstract}

Keywords: Hardness, sand casting, die casting, imported casting, clutch handle, aluminum alloy, and pattern.

\section{Introduction}

Foundry practice is one of the intermediary basic industries complementing forging and machining processes through which metallic raw materials like pig iron, crop ends (steel scrap), Ferro-alloys could be processed, refined and shaped into new products in the form of machine components and spare parts. (Agboola, 2008). The demand for the popular motor bike (Okada) its spare parts are so high that inferior products are sold and purchased with less regard to quality.

The rate of motorcycle accidents in Nigeria is so alarming that most state Governors have banned the use of motorcycles in their states. Most of these accidents are due to failure of some of parts of the motor bike while in motion. The nation has become a dumping ground for all types of imported motorcycle and its parts. We do not yet have our own foundry industries producing our own motorcycles and spare parts so as to easily control the quality of the products. The rate of parts failure in motorcycle especially the imported parts is quite alarming and require the intervention of professionals/agencies in quality control of the imported parts through local production. (Bam, etal, 2016). Hardness is a property of a material that enables it resist plastic deformation /failure or indentation, usually by penetration. It is not an intrinsic material detected by precise definition in terms of fundamental units of mass, length and time. It is a property of value defined in terms procedure. (Suluman etal, 2011).

Chemical composition plays a very important role in the quality and standard of a product (Buckerud and Sigworth, 1989). 


\section{Materials and Methods}

Moulding sand, moulding board, moulding box (cope and drag), shovel, trowel, vent wire, Bellow, pattern, runners (peen and flat), parting sand, runner peg, cast iron scraps, aluminum alloy scraps and melting furnace.

\section{Methods}

Moulding sand is sieved and mixed appropriately in the muller mixer with water.

When the necessary properties of the sand are achieved, the moulding sand is discharged and carried to the moulding section.

The pattern (motorcycle clutch handle) is placed on the moulding board and drag part of the moulding box placed on it as shown in plate 1

\section{Plate: 1. Drag placed on the moulding board with pattern. Moulding Process}

Moulding box (drag) is placed on the moulding board. The moulding sand is filled into the drag and rammed gradually till the mould is full. The mould is turned over to expose the pattern and smoothened with spoon tool and trowel. Parting sand is spread on top in order to aid the separation of the cope from drag. The cope part of the mould is placed on the drag, runner peg is placed on the mould and facing sand poured on the pattern. The sand is filled gradually and rammed till the mould is full. The mould is leveled and the runner peg removed. The mould is vented in order to allow escape of the mould gases. The cope is opened from the drag, the pattern is rapped in order to enable it to be withdrawn from the sand.

The ingate is cut in order to bring in the molten metal into the mould cavity as shown in plate 2 .

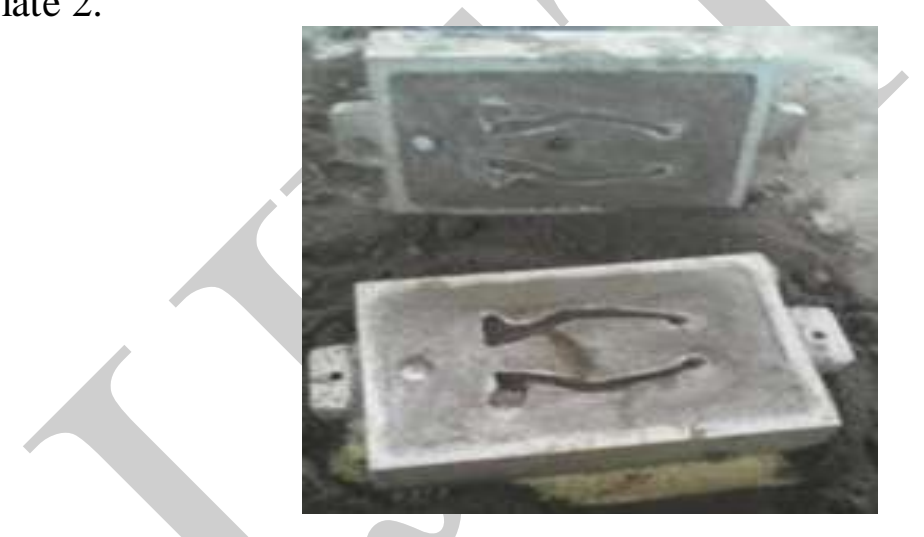

Plate 2. Ingate cut to admit molten metal

\section{Casting process}

Aluminum alloy scraps shown below are broken into smaller pieces.

The aluminum scraps are charged into the crucible pit melting furnace, it is lighted and heated till the metal get melted as shown in plate 3 .

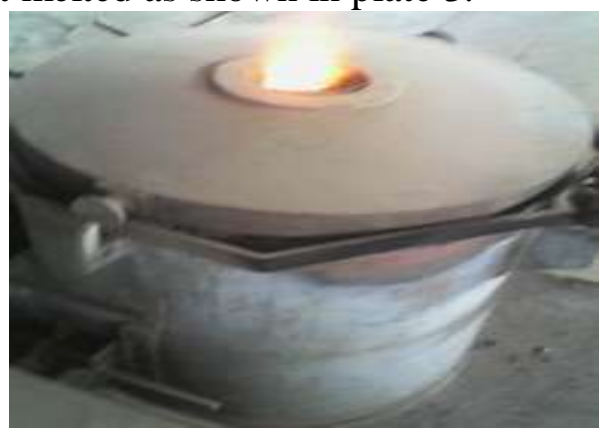




\section{Plate 3. Aluminum alloy been melted in the furnace}

The molten metal is collected with one man pouring shank and poured into the mould as shown in plate 4.

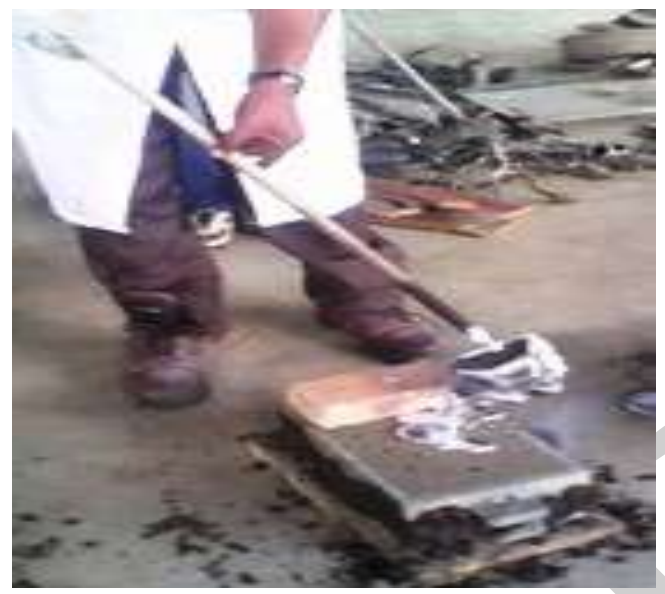

Plate 4: Molten Aluminum Alloy been poured into the mould.

When the molten metal has cooled and solidified, the mould is opened and the casting extracted and fettled.

Die casting process.

The dies made of cast iron and in halves of male and female are clamped together as shown in plate 5 and 6
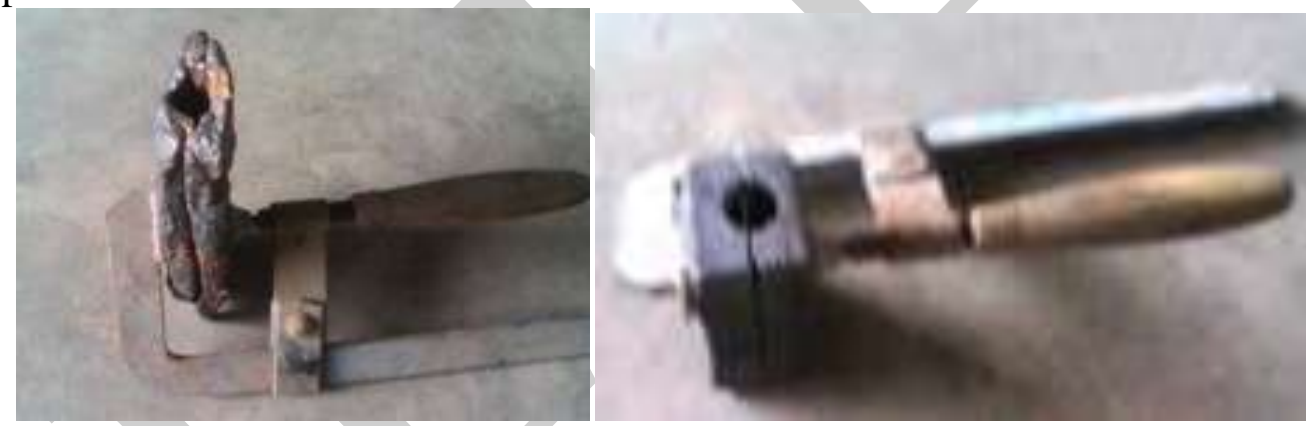

Molten aluminum alloy used in casting the motorcycle clutch handle is poured into the die.

When it has solidified the die casting is extracted. The casting is shaped in the dimensions of

Plate 5 and 6: Dies clamped ready to receive molten metal.

$20 \mathrm{~mm}$ X $20 \mathrm{~mm}$ X $20 \mathrm{~mm}$ as shown in plate 7 .

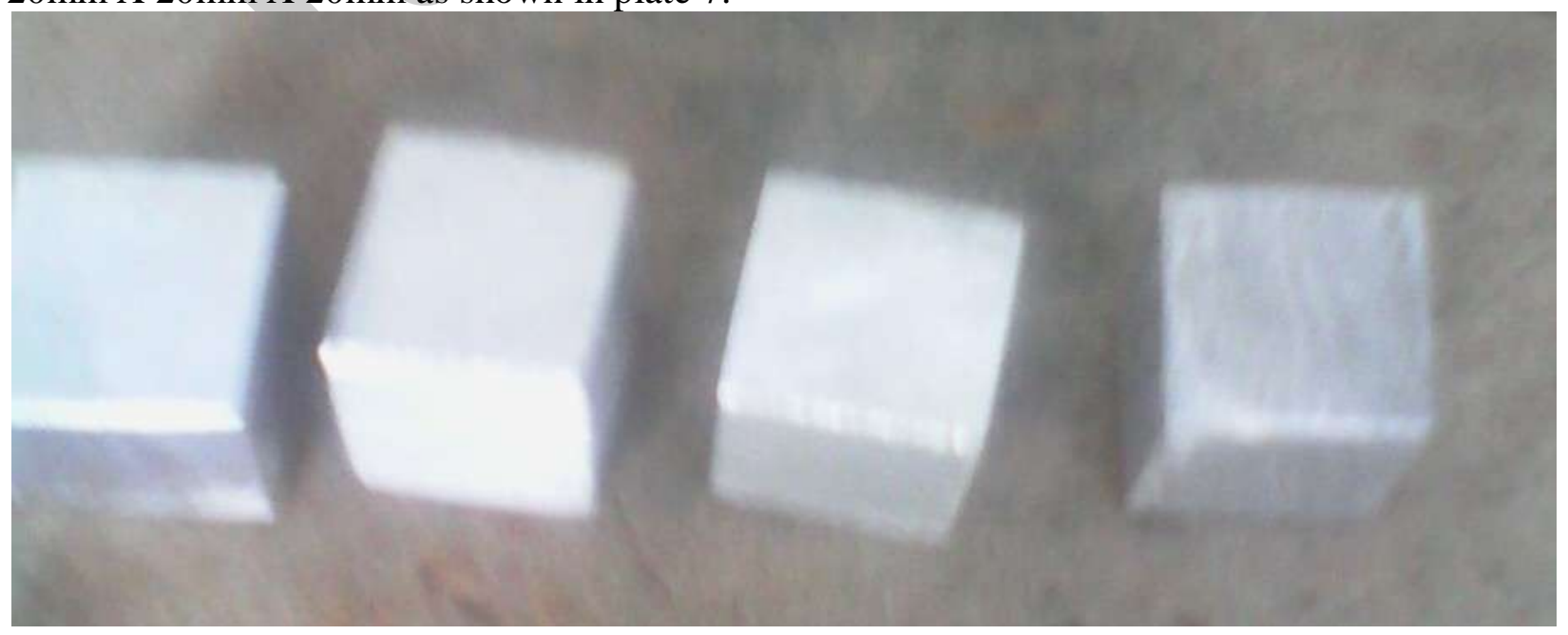


Plate 7: Test Specimen shaped in dimensions of $20 \mathrm{~mm}$ X $20 \mathrm{~mm}$ X $20 \mathrm{~mm}$

They are taken to Vickers hardness testing machine to test the hardness.

\section{Sand Cast Specimen Production}

Circular pattern pieces are produced with specified dimensions. Moulding sand is rammed inside the drag till the mould is full, it is turned and smoothened. Parting sand is spread on the face. The second part of the mould (cope) is placed on the drag. The patterns are fixed with runner and ingrate. The pattern specimen are fixed with runner and ingrate. The mould is rammed gradually till the mould is full. It is leveled and vented. The patterns and runner peg are removed.

The molten aluminum alloy used in casting the motor cycle clutch handle, the die cast specimen is used to cast the mould as shown in plate 8 .

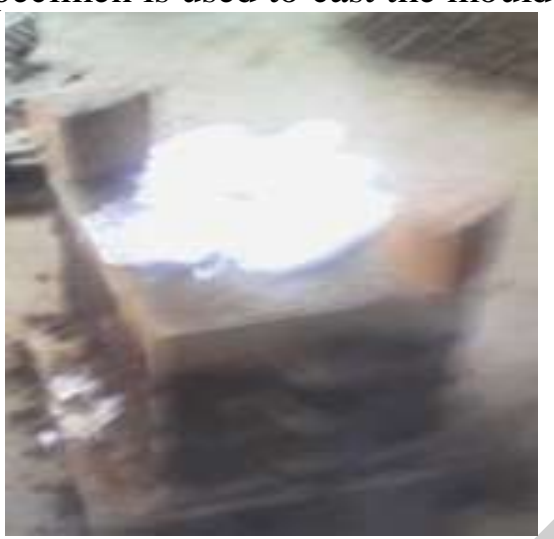

Plate 8: Molten aluminum alloy poured into the sand mould

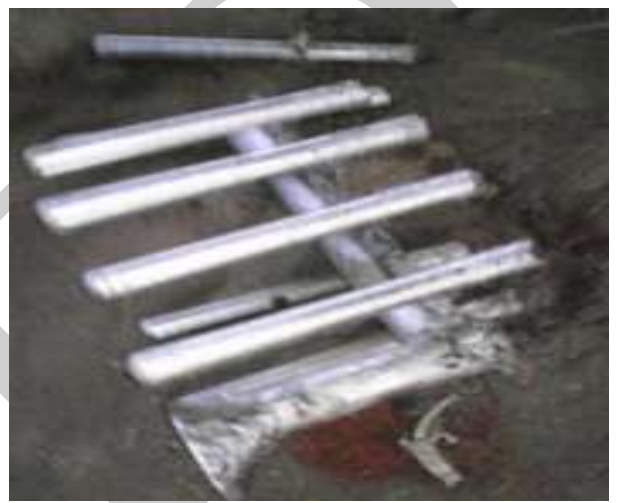

Plate 9: Casting been extracted from the sand mould

When the mold is cool and metal solidified the sand casting is extracted as shown in plate 9 .

It is taken to the sharpening machine and shaped to the shaped to the size of $20 \mathrm{~mm} \times 20 \mathrm{~mm} \times 20 \mathrm{~mm}$.

\section{TEST AND DISCUSSION}

The test results obtained from the sand cast specimen A1, A2, and die cast specimen A1, A2, are as shown in table 1.

\begin{tabular}{|l|l|l|l|l|l|}
\hline $\begin{array}{l}\text { S } \\
\boldsymbol{N}\end{array}$ & LABEL & $\begin{array}{l}\text { READIN } \\
\text { G 1 }\end{array}$ & READING 2 & READING 3 & AVERAGE \\
\hline $\begin{array}{l}1 \\
\text { Sand Casting } \\
\text { A1 }\end{array}$ & 124.7 & 117.4 & 128.3 & HV \\
\hline $\begin{array}{l}\text { H } \\
\text { Sand Casting } \\
\text { A2 }\end{array}$ & 132.2 & 145.0 & HV & 115.5 & 123.4 \\
\hline 4 & Die Casting B1 & 145.3 & 132.2 & 126.2 & 131.9 \\
\hline
\end{tabular}

LOAD: $980.7 \mathrm{mN}$

DWELL TIME: $\ldots 10$ 
Seconds

Calculating the average of the hardness of the two hardness test specimen

Sand Cast has the hardness of $127.65 \mathrm{HV}$

Die Cast has the hardness of $124.25 \mathrm{HV}$

Table 2: The test result obtained from imported cast specimen of aluminum alloy motorcycle clutch handle shown in below.

\begin{tabular}{|l|l|l|l|l|l|}
\hline $\begin{array}{l}\text { S/ } \\
\text { N }\end{array}$ & LABEL & READING 1 & READING 2 & READING 3 & AVERAGE \\
\hline & & HV & HV & HV & HV \\
\hline 1 & A1 & 90.9 & 79.0 & 85.8 & 85.2 \\
\hline 2 & B1 & 88.4 & 94.2 & 96.2 & 92.9 \\
\hline
\end{tabular}

DWELL TIME: $10 \mathrm{sec}$

TEST LOAD: $980.7 \mathrm{mN}$

Calculating the average of the two hardness test specimen

Imported cast has the harness of $89.05 \mathrm{HV}$

\section{Hv}

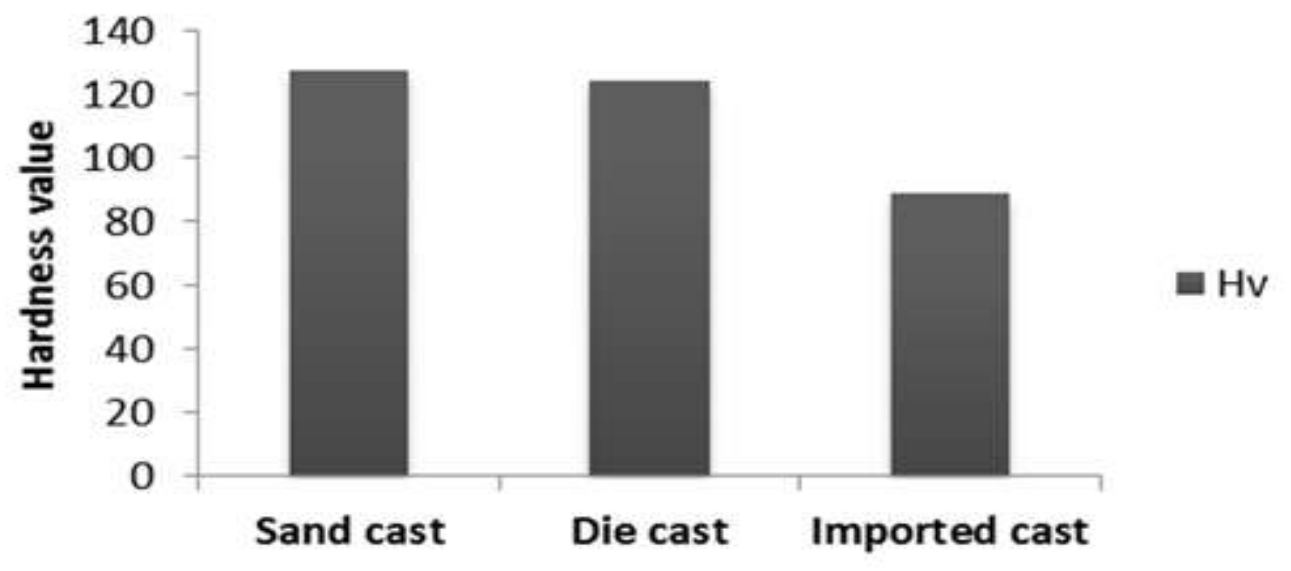

\section{DISCUSSION}

Calculating the average of the hardness of the two hardness test specimen sand cast has the hardness of $127.65 \mathrm{HV}$, die casting has the hardness of $124.25 \mathrm{HV}$ while imported casting has the hardness of $89.05 \mathrm{HV}$. These results clearly signify that both sand and die casting processes are very suitable for motorcycle clutch handle manufacturing.

\section{CONCLUSION}

It can be concluded that sand cast products are harder than die cast product and imported castings while imported casting will be more ductile as in the motorcycle clutch handle.

\section{RECOMMENDATION:}

Attention should be paid to foundry industries as to diversify the economy. 
Many of the raw materials required by foundries are available in the country but are in crude form. They should be explored, mined processed, characterized and standardized for use in automobile castings.

Foundry institutions should be established in Nigeria.

Foundry association of Nigeria should be supported to carry out its mandate.

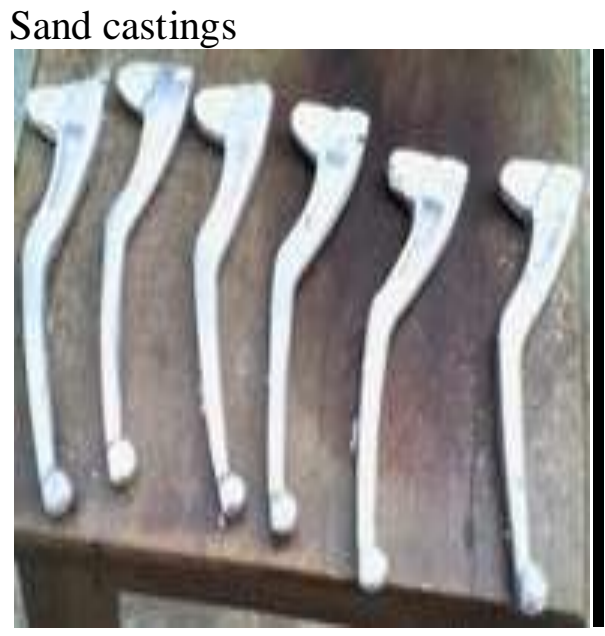

Die castings

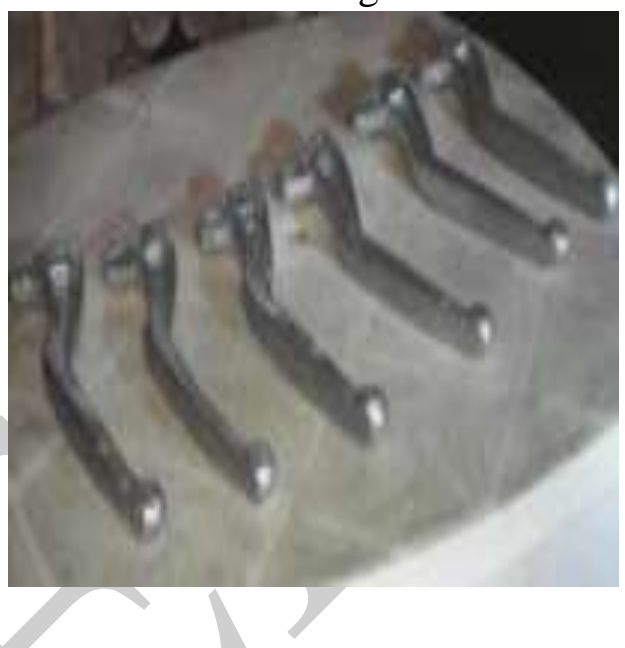

\section{Reference}

1. Anosike, C.O. (1995) Foundry Chronicle. A news letter published by the council of foundry association of Nigeria (FAN)

2. Bam S.A., Nyior G.B. and Ukachi,P.A. (2016) Comparative hardness of locally produced aluminium alloy motorcycle clutch handle with imported handle using sand die casting.International Journal of Academic Research and Development.ISSN:24554197.

3. www.newresearchjournal.com/academic. volum1; March 2016; pg 28-29

4. Backerud SL.GK. Recent Development in thermal analysis of aluminium casting alloys. AFS Trasnsactions, 1989. pg 459-464.

5. Foundry chronic, January-March, 1993 A newsletter published by council of Foundry Association of Nigeria. PPI

6. Foundry Chronicle, March, 1994, a newsletter published by the council of Foundry Association of Nigeria (FAN).

7. Suleiman S.Hamouda AMS, Abed in S, Usman MR. Simulation of metal filling processes during casting. Journal of materials processing Technology.2011; 100(1):224-229.

8. J.B. Agboola, 2008, "Present and future prospects of automobile casting in Nigeria, Publication of Nigerian metallurgical Society

9. Olorunfemi M.A. (1995) Foundry in the service of petroleum industry. A paper presented at foundry Africa 95, organized by Foundry Association of Nigeria (FAN).]

10. P. Beeley. 2001, Foundry Technology, Butterworth- Heinemann, A division of reed Educational and Professional Publishing Ltd.

11. Yatentengi M.A. (1995) The Nigeria market for Automobile components. A paper presented at Foundry Africa. 